\title{
СТАНОВЛЕННЯ КАТЕГОРІЇ «КУЛЬТУРА» В ФІЛОСОФСЬКІЙ ТВОРЧОСТІ ЯКОВА КОЗЕЛЬСЬКОГО
}

\section{М.Й. Заремський}

Розробка теоретичних (у тому числі філософських) проблем культури набуває нині важливого значення, оскільки є одним з необхідних моментів включення духовного простору України у загальний світовий контекст. Філософський аналіз культури має цінність і сам по собі, адже поза філософською рефлексією культура сприймається як щось фрагментарне, дискретне, позбавлене внутрішньої єдності й цілісності. Особливо актуальним $є$ дослідження категорії культури з позицій аналізу її становлення і розуміння в межах певних історико-філософських традицій. Оскільки такий аналіз здійснюється, як правило, на матеріалі західноєвропейської філософії, часто-густо починає домінувати думка про відсутність традиції визначення цієї категорії у вітчизняній філософії. Такий підхід, на наш погляд, $є$ абсолютно невиправданим.

В даній роботі ми ставимо за мету звернути увагу дослідників вітчизняної думки на певні аспекти творчості видатного українського мислителя XVIII ст. Якова Павловича Козельського (близько 1728 - після 1795). На нашу думку, є всі підстави стверджувати, що саме Якову Козельському українська філософія має завдячувати розробкою категорії «культура», хоча, на жаль, його ім'я часто навіть не згадується (що $є$ вкрай несправедливим!) у джерелах з історії вітчизняної культури. Практично відсутня така інформація й у тих нечисленних монографіях, які присвячені дослідженню філософської творчості Якова Козельськогороботах Ю. Когана, В. Дмитриченка, І. Щипанова, І. Бака, В. Демичева, О. Коробкіної, датованих 50-ми роками ХХ століття ${ }^{1}$.

${ }^{1}$ Див., напр.: Коган Ю.Я. Просветитель XVIII века Я.П. Козельский.-М., 1958.

Актуальні проблеми духовності

(Відп. ред.: Я.В. Шрамко)

Кривий Ріг (2005), 81-88 
Суть проблеми, що розглядається у статті, відображається засобами контекстуального аналізу становлення категорії «культура» у філософській творчості Я.П. Козельського. Це, на нашу думку, певною мірою має сприяти встановленню вітчизняних пріоритетів стосовно розробки власне українськими мислителями найважливіших філософсько-методологічних проблем та сформувати сприйняття нашої філософії як особливої, самостійної і різнобічної за змістом і напрямками течії світової філософської думки.

У сучасній філософії культури дослідження явищ культурного життя цілком природно розпочинається з визначення центрального поняття культурології-категорії «культура». При цьому аналіз їі становлення, як правило, проводиться на матеріалі західноєвропейської філософії ${ }^{2}$. Що ж стосується відносно самостійного формування змісту цієї категоpiї в історії вітчизняної філософської думки, то переважна більшість дослідників дотримується думки, згідно з якою термін «культура» вперше зафіксовано у творах Д. Велланського ${ }^{3}$. Загалом погоджуючись 3 цією тезою (поняття «культура» справді у вітчизняних філософських текстах до Д.М. Кавунника-Велланського не вживалось), все ж маємо зауважити, що поняття можуть передаватися описово, контекстуально, отже, відсутність терміну для означення певного змісту ще не означає відсутність поняття.

Не зупиняючись спеціально на дослідженні ролі перекладної літератури, російсько-іншомовних словників (на їх основі викристалізовувалися загальні фразеологічні структури), погодимося з авторитетними думками тих істориків філософії, котрі орієнтують дослідників на застосування контекстуального аналізу ${ }^{4}$, та націлюють на вивчення сукупності контекстів, співзначень, у яких вживаються терміни ${ }^{5}$.

Початок XVIII століття - це епоха поступової синхронізації розвитку вітчизняної культури з західноєвропейськими, епоха перекладів, епоха створення «республіки вчених» на теренах Російської імперії. Завдяки виданню масовими на той час тиражами наукових книг та інших видань забезпечувався синтез нового соціального досвіду і природничо-наукового знання. Соціальні, наукові, лінгвістичні процеси сприяли формуванню нових понять, систематизації мови науки, кодифікації граматики, уточненню етимології слів, складанню словників національних мов.

\footnotetext{
${ }^{2}$ Див., напр.: Сорокин Ю.С. Развитие словарного состава русского литературного языка (30-90-е годы ХІХ в.) - М.-Л., 1965.- С.95; Соколов Э.В. Культура и личность. - Л., 1972.-С. 23.

${ }^{3}$ Каменский З.А. Русская философия ХІХ века и Шеллинг. - М., 1980.- С. 110.

${ }^{4}$ Горский В.C. Контекстуальный анализ в историко-философском истолковании // Философские науки. - 1980. - №5.

${ }^{5}$ Плотников Б.А. Манифестация значения и её исследование // Проблемы семантики. - М., 1974.-С. 255.
} 
Який же саме соціально-етичний сенс вкладався просвітниками в поняття «культура»? Вчергове нагадуючи про те, що ідеалізована античність була зразком для філософії, літератури та мистецтва Просвітництва, відзначимо, перш за все, домінування в західноєвропейській філософіï буквального етимологічного перекладу слова «cultura», а також інші деривати від «colo» (наприклад, колонія, культ) ${ }^{6}$ у значенні «землеробство». Такий натуралізм в розумінні культури цілком відповідав поглядам на «природу» людини, «природний стан» тощо: індивід у мислителів Просвітництва визнавався не таким, що «виникає в ході історії,, а чимось даним від природи. Ця думка є своєрідним продовженням ідей Гесіода, Гомера, Катона Старшого, згідно з якими землеробство - не лише сама по собі обробка землі, але й найкорисніша і найблагородніша трудова діяльність, основа осілості, впорядкування буття, добробуту і підстава для формування громадських чеснот, традиційності життя, благочестя, фізичної і моральної досконалості, етичних начал. I не випадково в античності лексема «культура» крім землеробства означала також «виховання», «навчання,» «очищення» натури людини ${ }^{7}$. Можна сказати, що «землеробство - cultura» тлумачилося як діяльність, де реалізується єдність людини $з$ природою. 3 землеробством асоціювалася простота, природність, а саме природність і $є$ для просвітників розумною і корисною. Цікаво, що у найбільш прогресивній на той час педагогіці Дж. Локка знатним людям рекомендувалося «виховувати своїх дітей так, як добрі селяни своїх виховують» і стверджувалось, що «проста і груба натура сама собою кращою вважається, ніж вимислом прикрашена приємність» ${ }^{8}$.

Великий вплив на формування філософського розуміння культури, особливо на теренах Російської імперії, здійснили ідеї енциклопедистів, Ж.-Ж.Руссо. Згідно з цими ідеями є лише два справжніх багатстванаселення і оброблена земля. На необробленій, некультивованій землі живуть дикі народи. Більше того, Д. Юм в есе «Про торгівлю» (1752) стверджує, що й «поділ на класи залежить від переходу до землеробства від дикого способу життя» ${ }^{9}$.

Ж.-ЖК. Руссо йде ще далі: «от орания земли, - пише він, - последовало по необходимости разделение оной, а из собственности, единожды признанной, первые правила правосудия» ${ }^{10}$. Інші ж «художества» - винаходи в галузі металургії, «прирощування» мов, талантів, дослідів то-

\footnotetext{
${ }^{6}$ Поликарпов Ф. Лексикон треязычный.-М., 1704.-Л. 122, зв.

${ }^{7}$ Див.: Дворецкий И.Х. Древнегреческо-русский словарь.-М., 1958.-Т.1.С. 321 ; Його ж: Латинско-русский словарь.-М., 1976. - С. 276.

${ }^{8}$ Поповский Н.Н. Воспитание детей господина Локка, переведено с французского на российский язык профессором Н.Н. Поповым. - М., 1759. - Ч. І. - С. 5, 111.

${ }^{9}$ Юм Д. О торговле. Собр. соч. - М., 1965. - Т. 2. - С. 747.

${ }^{10}$ Р уссо Ж.-Ж. Рассуждение о начале и основании неравенства между людьми. Пер. П. Потемкина. - 2-е изд. - Тип. Н.И. Новикова, 1782. - С. 131.
} 
що - з'являються лише на основі землеробства: «возделывая поля, - пише Руссо, - мы образовываем свой ум» ${ }^{11}$.

Отже, землеробство розглядалося як основа появи власності, соціального розшарування і «громадянського життя». Ці думки Ж.-Ж.Руссо«женевського громадянина», «бессмертия достойного мужа, как высокопарного орла» ${ }^{12}$, як називав його Я. Козельський, отримали живий відгук у російських авторів. Так, С.Ю. Десницький слідом за Руссо виникнення власності пов'язує з землеробством: «Когда хлебопашство получило довольное приращение и приведено было в некоторое совершенство, тогда художества и рукоделия начали постепенно умножаться и в совершенство приходить» 13 .

Розширення форм діяльності в епоху промислового перевороту вело до більш абстрактного трактування і диференціації ряду понять, пов'язаних з працею, особливо тоді, коли економісти (перш за все-А. Сміт) від фізіократичних поглядів на землеробство як основу багатства перейшли до поняття абстрактної всезагальної діяльності-«праці взагалі». Саме таке значення абстрактної праці як джерела загального багатства відображається синонімом «культивація». Сфера багатства починає розглядатися не натуралістично, а як світ діяльності людини, спрямованого на створення нею вартостей. Діяльність вільного індивіда поступово протиставляється природі як проявові необхідності. Відбувається відчуження індивіда і культури від природи, остання починає розглядатися утилітарно, як всезагальний засіб виробництва товарів. Проблема відчуження землі, речей і майна починає займати все помітніше місце в роздумах російських філософів (С.Ю.Десницького і особливо Я.П.Козельського.) Про це свідчать вже початкові декларації частини III головного розділу «Юриспруденція»- «О должности человека в сношении с другими людьми» твору «Філософічні пропозиції» Я.П. Козельського: «Для выгоды человеческой жизни надобно быть отчуждению имений, то есть даче вещей из-под владения одного человека под владение другого» ${ }^{14}$.

Аналізуючи зміст названого розділу, варто було б звернути увагу на своєрідну «приземленість» змісту, коли у вічі впадає емпіричне тлумачення понять - як самоподвоєння уявлень, коли у спостереженнях, досвіді також вбачаються поняття. Пізніше, через 20 років після написання «Філософічних пропозицій», у творі «Міркування двох індійців Калана і Ібра-

\footnotetext{
${ }^{11}$ Руссо Ж.-Ж. Трактаты. М., 1969. - С. 262.

12 Козелъский Я.П. Философические предложения. Введение (1768). // Избранные произведения русских мыслителей второй половины XVIII века.- М., 1952. - Т. 1.С. 484 .

13 Див.: Избранные произведения русских мыслителей второй половины XVIII века. - М., 1952. - Т. 1.- С. 284.

${ }^{14}$ Козелъский Я.П. Вказ. праця.-С. 494.
} 
гіма про людське пізнання» (1788), в діалозі Калана та Ібрагіма вустами останнього Яків Козельський ще раз підтвердив правомірність і доцільність такого розуміння понять - задля їх чіткості і ясності: «Рассмотрите вы физику известного вам славного в нынешнее время философа: там все полезные и нужные материи о натуре преподаны как бы нарочно весьма темным образом, и хотя главный и единственный всех физических наук предмет есть натура, однако вы найдете там не натуру, изъясненную математикой, как бы надлежало, а математику, налагающую натуре свои законы; но это напрасно и весьма некстати: натура никогда не училась у математики, а, напротив того, математика - у натуры, которая всех наук умнее и превосходнее» ${ }^{15}$. Зазначене наштовхує на висновок про прихильність Козельського до позиції К.А. Гельвеція стосовно того, що «будь-яка ідея може бути зведеною до фізичних фактів або відчуттів» ${ }^{16}$, а поняття можна вивести із сприймань, і в черговий раз підтверджує думку сучасного дослідника епохи Просвітництва Мішеля Фуко, який підкреслює: «... впродовж всього класичного століття мова утверджувалась і розглядалася як дискурсія, тобто як спонтанний аналіз уявлення» ${ }^{17}$. Шо ж стосується терміну «культура», то формування цього поняття відбувалося у типових рисах, властивих для понятійних систем взагалі: смислова диференціація на основі відтінків і контекстів цього терміну здійснювалась повільно, науковий зміст закономірно мав «пережити» етап існування серії термінів, термінологічного ряду, аналогів.

Однією з характерних особливостей Просвітництва є саме те, що в цю епоху було здійснено уточнення змісту і класифікацію попередніх термінів i формування нових синтетичних понять. Звичайно ж, на вітчизняному грунті ці процеси відбувалися дуже складно, а особливо з урахуванням вимог стилістичних реформ В.К. Тредіаковського і М.В. Ломоносова стосовно «захисту» російської мови від іншомовних слів, що уповільнювало формування російської філософської термінології. Через те поняття «культура» зайняло своє місце як філософська категорія лише в 20-30$\mathrm{x}$ роках нового століття, і то під впливом ідей I. Канта - «законодавця мод» на філософському поприщі Європи початку XIX століття. Міркування кенігсберзького мислителя яскраво відобразили розуміння ним відтінків значень термінів «дисципліна» і «культура»: для виховання таланту культура має позитивне, а дисципліна - негативне значення, оскільки культура сприяє формуванню навичок, а дисципліна звільняє нас від «деспотизма вожделений» 18 .

\footnotetext{
${ }^{15}$ Козелъский Я.П. Разговор двух индийцев Калана и Ибрагима о человеческом познании (1788). // Избр. произв...-С. 576.

16 Див.: Гельвеиий К.А. Об уме.-Соч., М., 1977.- С. 30.

17 Фуко М. Слова и вещи.-М., 1977.-С. 30.

${ }^{18}$ Кант И. Собр. Соч.-М., 1966.- Т.5.-С.465; див. також: Кант И. Собр. Соч.
} 
Ставлячи перед собою завдання фундаментального дослідження проблем свободи людини, Кант знаходить найвідоміший термін для виразу специфічно людського способу освоєння світу - «культурного»: це $є$ свобода усвідомлювати і формулювати мету, змінювати (і покращувати!) природу, суб'єкта цього процесу - людину. Але І. Кант не є автором принципово нового тлумачення культури: для нього вона, як і для попередників, пов'язана з обробкою землі, з появою власності (а на її основі - нерівності), громадянського устрою ${ }^{19}$. Хоча, звичайно, сам термін «культура» німецьким філософом вже активно використовується.

Ми поділяємо думку М.О. Булатова стосовного того, що, попри наявність у вченні Канта майже цілковитої визначеності категорії «культура», сам автор «коперніанського перевороту» $\dddot{11}$ до кінця не усвідомлював ${ }^{20}$. На користь такого розуміння, зазначає М. Булатов, свідчить не тільки загальне розуміння категорії як форми культури, але й ті тексти, в яких прямо вживається термін «культура». І. Кант, як відомо, застосовує цю дефініцію в кількох значеннях. По-перше, в своєму творі з історії філософії німецький мислитель користується поняттям «культура» при характеристиці протилежності і подальшого розвитку природи : «Вся культура и искусство, украшающие человека, самое лучшее общественное устройство - всё это плоды необщительности, которая в силу собственной природы сама заставляет дисциплинировать себя и тем самым посредством вынужденного искусства [виділено нами - М. 3.] полностью развить природные задатки» ${ }^{21}$. М.О.Булатов відзначає й інші відтінки розуміння Кантом культури і застосування ним цього поняття. Так, характеризуючи конфліктний, антагоністичний характер міжлюдських стосунків, родоначальник німецької класичної філософії прогрес суспільного життя вбачає у переході «від грубості до культури, яка, власне кажучи, полягає в суспільній цінності людини» ${ }^{22}$. Отже, культура, за Кантом, виникає і розвивається в результаті суспільного антагонізму, а не в силу вродженого прагнення людей до щастя.

Не можна залишити поза увагою й те, що, слідом за Ж.-Ж.Руссо, Кант критикує цивілізацію, хоча ця критика не має такого однобоко негативного відношення до неї. Цивілізація, безжалісна до окремої людини, одночасно являє собою безсумнівний прогрес по відношенню до всього роду людського. Мета природи досягається в ній по відношенню до су-

M., 1964.-T.3.- C. 598.

${ }_{19}$ Див.: Кант И. Трактаты и письма. - М., 1980.-С. 54.

20 Див.: Булатов М.А. Диалектика и культура (историко-философский анализ).К.: Наукова думка. - 1984.- С. 84.

${ }^{21}$ Кант И. Идея всеобщей истории во всемирно - гражданском плане. - Соч.: В 6ти т. - М.: Мысль, 1966.-Т. 6.-С.13.

${ }^{22}$ Там же.- С. 11. 
спільства в цілому, а не до окремого індивіда. Тому сама природа штовхає людину до виходу з суперечностей цивілізації і її переходу до справедливої правової організації суспільства. Наявність такої організації виступає вирішальною умовою досягнення природою своєї кінцевої мети у відношенні до людини. Отже, правове суспільство має стати вищою метою для людського роду в процесі його історичного та культурного розвитку.

Оскільки предметом наших пошуків є все ж дослідження місця і ролі Якова Козельського у розвитку філософії XVIII століття, зауважимо, що зміст «Філософічних пропозицій», логіка викладу думок українського філософа за розділами, главами, частинами засвідчує цілісність його філософських позицій, розуміння складної системи зв'язків соціальних явищ як підгрунтя формування «практичної філософії». Так, в одному з фрагментів (випереджаючи Канта на два десятки років - думки українського мислителя з «Філософічних пропозицій» 1768 року перегукуються з положеннями «Критики здатності судження» 1790 р.) про необхідність створення досконалого громадянського суспільства для дисциплінування людей, схильних до особистої свободи, аби останні мали б підпорядковувати свою волю інтересам цілого, що дозволило б їм вступити в громадський союз ${ }^{23}$, Яків Козельський зазначає: «Благополучие целого народа состоит в том, когда каждый из его членов теряет малую часть своих удовольствий, чтоб преобресть на место того несравненно большую, потому что все люди в обществе желают имения, чести, славы, покоя, веселья и прочее; и когда они все желать будут того беспредельно, то трудно комулибо из них быть благополучным; а ежели каждый из них уступит одно какое-либо из своих или по малой части их всех желаний обществу, то через то они без изъятия все почти во всех своих желаниях будут удовольствованы и потому благополучны» ${ }^{24}$.

Дослідник проблеми становлення категорії «культура» О.М. Лисюткін в своїй статті пише: «Интересно, что близкие Канту идеи развивал в Философических предложениях» [1788] (виділено нами - М.З.) Я.П. Козельський» ${ }^{25}$. Тут, перш за все, впадає у вічі така деталь: О. Лисюткін декілька разів ${ }^{26}$ - випадково чи ні- повторює суттєву помилку: насправді, як нам відомо, «Філософічні пропозиціі» Козельського були написані двадцятьма роками раніше - у 1768, а не у 1788 році. На цей час у Канта не було написано ні однієї з його знаменитих «Критик». А отже, не Козельський повторює Канта, а навпаки: близькі до позиції Козельського ідеї

\footnotetext{
${ }^{23}$ Кант И. Критика способности суждения.-Соч.: В 6-ти т.-Т.5.-М., 1966.C. $464-465$.

${ }^{24}$ Козельский Я.П. Философические преложения // Избр. произв...- С. 256.

25 Лисюткин О.М. K вопросу о становлении категории «культура» (XVIII- начало ХІХ вв.) // Философские науки. - 1982.-№3.-С. 105.

${ }^{26}$ Там же. - С. $103,104,105$.
} 
згодом висловив і І. Кант. Український філософ, аналізуючи зміст теорії суспільного договору Руссо, пише: «Человек при перемене натурального состояния в гражданское приобрел в поступке своем справедливость вместо побуждения, в делах своих нравоучение, на место безобразной слепоты, и во всем своем житии - должность вместо натурального понуждения, и следует разуму, не слушаясь своей склонности; и хотя он через сию перемену лишается многих натуральных выгод, однако на место того приобретает другие великие качества, способности его беспрестанно возрастают, понятия распространяются, мысли делаются благороднее, и в вся его душа возвышается до такой степени, что ежели злоупотребление нового сего состояния не сводило его часто ниже натурального, то должен бы он беспрестанно благословить то время, которое его вывело из того состояния и сделало с безумного и ограниченного животного разумным и человеком» ${ }^{27}$. Показовим $\epsilon$ й продовження: «В гражданском состоянии получает человек еще нравственную вольность, которая делает его господином над самим им, потому что побуждение желания есть рабство, а повиновение предписанным законам есть вольность» ${ }^{28}$.

Таким чином, свобода і культура кваліфікуються Я.Козельським не як природовідповідність, слідування законам природи, а як цілепокладання незалежної особистості в громадянському суспільстві, вдосконалення розумових і фізичних здібностей, звичаїв, моралі. Залишаючись в цілому виразником «класичної» моделі культури, не будучи здатним перевершити їі інтелектуальний горизонт, Козельський багато у чому наповнює розуміння культури новим змістом ${ }^{29}$, разом з тим об'єднуючи різноманітні явища суспільного життя в одну цілісність, що згодом - у наступників стане передумовою її осмислення як філософської категорії.

Отже, на прикладі філософської творчості українського мислителя епохи Просвітництва Якова Павловича Козельського можна прослідкувати складну еволюцію поняття «культура»: відбувається свого роду «зняття» старої античної полісемії терміну і виникнення нової, більш синтетичної і абстрактної.

\footnotetext{
${ }^{27}$ Козельский Я.П. Вказ. праця. - С. 180.

28 Там же.

${ }^{29}$ Хоча, звичайно, категорія «культура» ще чітко не окреслена, не озвучена, її зміст часто передається описово, за допомогою інших слів і словосполучень
} 